\section{J. Meyer}

Department of

Practical and Missional Theology, UFS. Email: meyerj1@ufs.ac.za

DOI: http://dx.doi. org/10.18820/23099089/ actat.v38i1.9

ISSN 1015-8758 (Print) ISSN 2309-9089 (Online)

Acta Theologica 2018 38(1):148-153

(c) UV/UFS

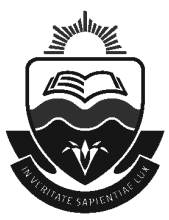

REVIEW

AN INTRODUCTION TO PRACTICAL THEOLOGY: HISTORY, THEORY, AND THE COMMUNICATION OF THE GOSPEL IN THE PRESENT

GRETHLEIN, C. (Waco, Texas: Baylor University Press, 2016) 264pp. ISBN: 9781481305174

In this volume, originally written in German, Grethlein (2016) builds a systematic and summarised argument for a Practical Theology oriented to the international platform and integrated with ecclesial aspects (p. vii). Nevertheless, the book is mainly aimed at addressing the most pertinent issues within the German context, from where it has developed over a period of 200 years (p. vii-viii). Grethlein ( $p$. viii) himself states in the foreword that his arguments "are based on observations that practical-theological theorizing and, in consequence, ecclesial praxis are encumbered with an imprecise terminology that impedes an accurate and theologically reflected perception of present-day reality".

This provides the basis for the imperative of this book, in which the author compares the profile of Practical Theology, as developed in Germany, to that of Practical Theology in the Catholic Church and in the United States of America, with the aim of developing a communication theory-oriented analysis that is sensitive to the particularities of different contexts, but still reveals the innovative potential inherent in Jesus' appearance, ministry and destiny, particularly for the development of Practical Theology (p. viii). 


\section{PART I: HISTORICAL INTRODUCTION TO PRACTICAL THEOLOGY}

After providing an in-depth analysis of the development of Protestant Practical Theology in Germany, parallel to the development of this field in the Catholic Church in Germany and in the United States of America, respectively, Part 1 of this book proposes that Practical Theology, as both theory and praxis, "can only be understood in relation to its different contexts" (p. 58). Grethlein draws this conclusion from both the German Protestant Theological context and the successes and failures of different approaches in diverse and changing contexts. In the development of Practical Theology as a theory of Balances (p. 59), Grethlein makes several remarks, of which the most important are that contemporary religious and spiritual practices conflict with a "well-defined subject of study necessary to research practice" and that the theology lacks the inclusion of nontheological insights and research strategies into its selection of thematic focuses. As both a consequence and a cause, the discipline of Practical Theology lacks relevance to the praxis of Theology and remains in conflict with multiperspectival approaches required by the complexity of life, also interpreted as the lived experiences of people (cf. p. 59).

In the same section, the author highlights the inadequacies of German Protestant Practical Theology, as deduced from the comparison of the various Practical Theology profiles in both the Catholic Church and the United States of America. The first noted inadequacy is that German Practical Theology lacks emphasis on important political and socioeconomic questions, as it relates to the social structure of Germany. Secondly, German Protestant Practical Theology does not provide an adequate theological definition of its own discipline, as deduced from its perception of cultural discourses. Finally, Practical Theology escapes functional availability, as it fails to distinguish between the ideas of God and those of human beings, or the church (p. 59).

In finalising Part 1, Grethlein (p. 59) proposes that the communication of the gospel, as the main imperative, is born from the idea that it correctly describes and defines the primary subject of the discipline of Practical Theology, and that, as such, it relates constructively to nontheological sciences. As a consequence, it has the ability to examine the "context of a democratic society and pluralistic cultures" - or differently stated - it has the potential to enter in dialogue with everyday living practices. 


\section{PART II: PRACTICAL THEOLOGY AS THE THEORY OF THE COMMUNICATION OF THE GOSPEL}

Grethlein defines the object of Practical Theology as the communication of the gospel in the present. This definition is placed in the framework of the "problem-historical reconstruction of Practical Theology" (p. 182). Grethlein postulates that Practical Theology has always been oriented towards contemporary life and, as such, clarifies some essential concepts related thereto. In principle, the notion of "communication" provides an opportunity for Practical Theology to enter in dialogue with nontheological disciplines. In turn, the notion of "gospel" re-engages Practical Theology with various theological disciplines (p. 183). Grethlein (p. 184) argues that the notion of "religion" - as an essentially Protestant concept of distinction - is still understood through the connection between church doctrine and various Christian practices. This concept - as it is presently adapted to include non-Christian forms of value orientations - is at risk of tacitly containing Christian "footprints". Alternative to the notion of "religion", that of "spirituality" is used more frequently, as studies in Practical Theology and communication have realised that people aspire towards new life and value orientations independent of "organization", or "institution", which necessarily includes the church (p. 184).

Henceforth, Grethlein (p. 183) suggests the use of two different hermeneutical models in the analysis of the theory of communication of the gospel in the present. In preventing academic contrapositioning, Grethlein (p. 183) recommends distinguishing between primary and secondary religious experience, by employing media-theoretical transformation, which ensures that the connection between these two concepts is not lost in translation. Secondly, for a distinguished look at the transformation of the gospel, the liturgy hermeneutical model can be employed. This model distinguishes between "transcultural, contextual, countercultural, and cross-cultural dimensions of the communication of the gospel" and can relocate it to other forms of communicating the gospel, while grounding it in fundamental Christian imperatives.

Grethlein (pp. 183-184) describes the context and framework in which the three processes towards communicating the gospel, take place. The "culture-historical and knowledge-sociological conditions" of communicating the gospel nowadays is traced by Taylor's concept of secularity and Knoblauch's concept of popular religion. The second process is earmarked by immense changes in living conditions, such as an increase in life expectancy; changes in family and work life, and global migration. These changes inevitably transform the ways in which the 
gospel is communicated. The final process is characterised by changes in social life, especially the incorporation of media technology into forms of communication and socialisation (p. 185).

This section concludes with a discussion of ways in which the three modes of communicating the gospel are contextualised for current lived experiences. With reference to the modes of teaching and learning, Grethlein (p. 184) states that there exists "a great variety of places for learning and didactical approaches", but that the current German focus on schooling poses a challenge to the theory of communication. The mode of communal celebration, however, coexists commonly with "official ecclesial forms of celebration", and is practised privately by the vast majority of people. The mode of helping for living, however, has been surpassed by the former two modes, despite its "close relationship between action and community" (pp. 184-185). In this instance, it is noted that the practice of this mode is contextualised in the private lives of people, independent of the actions of organized churches (p. 185).

\section{PART III: METHODS FOR THE COMMUNICATION OF THE GOSPEL}

At the beginning of Part III of this book, Grethlein (p. 188) emphasises that "God's love is fulfilled in communicative processes", and more specifically in "the modes of teaching and learning, celebrating together and helping for living". However, he makes the reader aware that, in order to create the appropriate space for these forms of communication to take place, time and space should be treated in specific ways. These three modes of communicating the gospel inherently suggest three modes of contact with God: "The mode of teaching and learning communicates about God; celebrating together communicates with God; and helping for living taps into God's strength. God is neither 'concept' nor 'experience', but concretely subject, goal and origin of communication" (p. 189).

In concluding part III, and the book as a whole, Grethlein suggests that a Practical Theology, which centres on the communication of the gospel, will analyse concrete methods within concrete contexts. As such, he suggests that communication theory and theological precision should be utilised to develop insights related to traditional practical theological disciplines.

Grethlein concludes this book with a few final remarks (pp. 253-254), of which the first is the observed continuity of the three elementary communicative forms that provide the foundation for the communication of the gospel. Grethlein adds that, in contrast to this, the sacralisation of these three forms of communication through dogmatic history (e.g., preaching, 
celebrating the Lord's Supper, and baptising) abstruse their value for daily living. As a result, it should be transformed into a form of communication (celebration) that can be understood by everyone. The manner in which Grethlein (p. 76-81) proposes to transform the sacralisation of these communicative acts is inevitably by re-categorising it: 1) Teaching and Learning; 2) Communal Celebrations, and 3) Helping for Living. As the situation stands in Germany, these forms of communication are restricted to their specific domains, namely education, music and the health sector, although they are, unofficially and surprisingly, practised by many people in multilocal and multigenerational families. It appears then that the essential task for Protestant Practical Theology is to make knowledge previously reserved to the educated middle class - available for everyone to use in daily life in many different needs-related contexts. In essence, Grethlein (p. 254) concludes, that people's needs should be incorporated into a "theory-driven praxis".

At first glance, the relevance of this book to the South African context seemed limited. However, it soon became clear that the development of not only the Protestant Church in Germany, but also other ecclesial developments within a changing Germany and United States of America have, indeed, many similarities to the South African context. The latter is also characterised by changes in communicative structures and technologies, notwithstanding the changes in the political spheres, albeit some years later. Inevitably, the Protestant Church and Practical Theology in South Africa can find value in a communicative model that stands in a constructive relationship with both nontheological sciences and the pluralistic nature of our unique society, on both a secular and religious level.

In reading Grethlein's evaluation of the socioreligious context of Protestant Germany, one cannot help but wonder what such an analysis of this context in South Africa will deliver. Notions of teaching and learning limited to educational institutions, as well as helping limited to the health sector seem all too familiar. In being context-sensitive and, therefore, careful to apply findings from one context to another, the conclusion is made that this model for communicating the gospel can, at the very least, add value to the awareness of the South African practical theologian's (and the Church's) understanding of how communication operates in the modern globalised, albeit post-colonised and postapartheid South Africa. Grethlein's model for communicating the gospel - simple in its complexity - raises the awareness that "God's love is fulfilled in communicative processes" (p. 188) and that, through the three modes of communicating the gospel, God's love can be communicated in all contexts, to be used constructively during daily living. This book, therefore, delivers a comprehensive analysis of the state and development of Practical Theology over a 200-year span. Consequently, it gives birth 
to a constructive model for communicating the gospel with the use of three different, yet practical modes of communication that keep pace with the development of communication in not only secular spaces, but also nontheological sciences. 